\title{
The Glucose Lowering Effect of Zornia gibbosa Span Extracts in Diabetic Rats
}

\section{Diyabetik Sıçanlarda Zornia gibbosa Span Ekstrelerinin Glukoz Düşürücü Etkisi}

\author{
(D) Mallikarjuna Rao TALLURI*, (D) Rajananda Swamy TADI², (D) Ganga Rao BATTU², (D) Mohammad ZUBAIR ${ }^{3}$ \\ 'Anacipher Clinical Research Organisation, Department Bio-Analytical, Telangana, India \\ ${ }^{2}$ Andhra University, College of Pharmaceutical Sciences, Department of Pharmacognosy and Phytochemistry, Andra Pradesh, India \\ ${ }^{3}$ University of Tabuk, Faculty of Medicine, Department of Medical Microbiology, Tabuk, Kingdom of Saudi Arabia
}

\begin{abstract}
Objectives: Diabetes mellitus is a chronic, lifelong condition that affects our body physiology. Untreated diabetes mellitus causes diseases such as diabetic retinopathy, diabetic nephropathy and diabetic neuropathy, auto immune diseases, polyuria, polydipsia, loss of weight, and cardiovascular diseases. The use of medications for the treatment of diabetes mellitus causes adverse effects with long-term use, and sometimes leads to death. Today, researchers are working on the discovery of new anti-diabetes drugs from plants with low or no adverse effects. From this point of view, the present work was conducted to evaluate the anti-diabetic activity of Zornia gibbosa Span.

Materials and Methods: This acute toxicity study was conducted for ethyl acetate and ethanol (70\%v/v) extracts of $Z$. gibbosa as per OECD guidelines. The anti-diabetic activity of selected plant extracts were tested using alloxan-induced diabetes in a rat model.

Results: No mortality was observed in the administered doses of Zornia gibbosa Span extracts. The tested extracts significantly ( $\mathrm{p} \leq 0.01)$ restored the physiologic changes that occurred due to the alloxan-induced diabetes mellitus. The hydroalcoholic extracts at $500 \mathrm{mg} / \mathrm{kg}$ body weight concentration showed more activity compared with other extracts at different concentrations along with standard drug (glibenclamide). Zornia gibbosa significantly decreased glucose concentrations and restored the altered enzymes levels caused by damage to different organs by diabetes. Conclusion: The results of the present study indicate that $Z$. gibbosa has a significant anti-diabetic activity. Therefore, it may be capable of use as an alternate medicine along with allopathic medicine in the treatment of diabetes as well as its health problems.
\end{abstract}

Key words: Zornia gibbosa Span, diabetes mellitus, alloxan, glibenclamide

Öz

Amaç: Diyabet, vücudumuzun fizyolojisini etkileyen, yaşam boyu kronik bir hastalıktır. Tedavi edilmeyen diabetes mellitus, diyabetik retinopati, diyabetik nefropati ve diyabetik nöropati, otoimmün hastalıklar, ploiüri, polidipsi, kilo kaybı ve kardiyovasküler hastalıklar gibi hastalıklara neden olur. Diabetes mellitus tedavisinde kullanılan ilaçlar, uzun süreli kullanımda yan etkilere neden olur, bazen ölüme yol açar. Günümüzde araştırmacılar, yan etkileri düşük veya hiç olmayan bitkilerden hareketle yeni anti-diyabetik ilaçların keșfedilmesi üzerinde çalıșmaktadır. Bu açıdan, mevcut çalıșmada, Zornia gibbosa Span'ın anti-diyabetik etkinliğinin değerlendirilmesi amaçlanmıştır.

Gereç ve Yöntemler: Akut toksisite çalışması OECD kılavuzlarına göre Z. gibbosa'nın etil asetat ve etanol (\%70 v/v) ekstreleri için yürütülmüştür. Seçilen bitki ekstrelerinin anti-diyabetik aktivitesi, sıçanlar üzeinde oluşturulan alloksan-nedenli diyabet modeli kullanılarak değerlendirilmiştir.

Bulgular: Zornia gibbosa Span ekstrelerinin uygulanan dozlarında herhangi bir ölüm görülmemiștir. Ekstreler, alloksan-nedenli diabetes mellitus nedeniyle oluşan fizyolojik değişiklikleri önemli ölçüde ( $p \leq 0.01)$ iyileştirmiştir. $500 \mathrm{mg} / \mathrm{kg}$ konsantrasyonundaki sulu-alkollü ekstreler, standart ilaç (glibenklamid) ile birlikte farklı konsantrasyonlardaki diğer ekstrelerle karşılaşıırıldığında, daha yüksek aktivite göstermiștir. Z. gibbosa glukoz konsantrasyonunu önemli ölçüde düşürmüș ve diyabetin değişik organlara hasar vermesi nedeniyle değișen enzim düzeylerini iyileștirmiştir.

Sonuç: Bu çalışmanın sonuçları, Z. gibbosa'nın önemli anti-diyabetik etkiye sahip olduğunu göstermektedir. Bu nedenle, diyabet tedavisinde ve diyabetin neden olduğu diğer sağlık problemlerinde Z. gibbosa'nın allopatik tıp ile birlikte kullanılabileceği ortaya konulmuştur.

Anahtar kelimeler: Zornia gibbosa Span, șeker hastalığı, alloksan, glibenklamid

*Correspondence: E-mail: tmrao1987@gmail.com, Phone: +91 9032146226 ORCID-ID: orcid.org/0000-0002-9242-709X

Received: 12.09.2017, Accepted: 09.11.2017

-Turk J Pharm Sci, Published by Galenos Publishing House. 


\section{INTRODUCTION}

Glucose is a simple sugar found in all foods and an essential nutrient that provides energy for the proper functioning of body cells. However, it cannot be delivered alone to cells and it needs insulin to aid its transport into the cells. Insulin is a hormone produced by specialized cells ( $\beta$-cells) of the pancreas. Without insulin, cells become ravenous for glucose because carbohydrates are broken down in the small intestine and the glucose in digested food is then absorbed by the intestinal cells into the bloodstream, and is carried by the bloodstream to all cells in the body where it is used.1.2 High blood sugar levels over a prolonged period causes diabetes mellitus (DM). DM is a chronic, lifelong condition that affects our body's ability to use the energy found in food. There are three major types of DM. One is type $1 \mathrm{DM}$, which results from the pancreas's failure to produce enough insulin. In type $2 \mathrm{DM}$, either the amount of insulin produced is not enough for the body's needs, or the body's cells are resistant to it, and finally the third is gestational diabetes, which occurs in pregnant women. ${ }^{3-6}$

Globally, an estimated 415 million people have DM. ${ }^{7}$ In the last three years, 1.5 to 5 million deaths occurred per year due to DM. All three forms of DM increase the risk of long-term complications. ${ }^{8,9}$ The main complication due to DM is damage in the blood vessels. Untreated DM affects primary organs of the body such as the eyes, kidneys, and nerves by causing diseases diabetic retinopathy, diabetic nephropathy and diabetic neuropathy, auto immune diseases, polyuria, polydipsia, loss of weight, and cardiovascular diseases. Low levels of insulin cause the liver to turn fatty acids into ketone bodies for fuel instead of glucose, which causes ketosis. This in turn decreases the blood $\mathrm{pH}$ levels, which causes severe dehydration, hypotension, and finally death. These evets mainly occur in type $1 \mathrm{DM} \mathrm{M}^{1.10-12}$

DM is a chronic disease, for which there is no cure, mainly for type 1 DM. 'Blood sugar levels of patients with type 2 DM and gestational DM can be controlled with a healthy diet, exercise, weight loss, and use of appropriate medications, but there is no cure. ${ }^{2}$ Blood glucose (sugar) levels of patients with type $1 \mathrm{DM}$ are controlled by taking insulin. Patients with type 2 and gestational DM use oral medications such as biguanides (metformin), ${ }^{13}$ sulfonylureas (tolbutamide, glibenclamide, glimepiride), and thiozolidinediones (pioglitazone, rosiglitazone). The use of these medications causes adverse effects with long-term use, ${ }^{14,15}$ sometimes causing severe acute diseases and lead to death. The adverse effects are mainly rapid or shallow breathing; painful or difficult urination; anxiety; blurred vision; chest discomfort; depression; irregular, pounding, or racing heartbeat or pulse; behavior changes similar to being drunk, difficulty with concentrating, drowsiness; lack or loss of strength; and restless sleep. Therefore, safer and more effective anti-diabetic drugs are still urgently needed. ${ }^{16}$

Natural products, mainly herbal medicines, have been playing an important role in treating diabetes around the world for centuries particularly in Asia, India, and Africa. ${ }^{17.18}$ Many researchers are working on the discovery of new antidiabetes drugs and have reported many new plants and their extracts' anti-diabetic activity using advancements of novel technology. 19,20 These findings provide valuable leads for the development of new isolated compounds for the treatment of diabetes. ${ }^{21}$ However, there are still many medicinal plants available to screen for their biologic activities for disease including diabetes. Many pharmaceutical companies and academic laboratories are engaged in the discovery of new targets, pathways, and treatments for diabetes to supplement the current chemotherapies. ${ }^{22}$ From this point of view, the present work was conducted to evaluate the anti-diabetic activity of Zornia gibbosa (Z. gibbosa) based on its traditional use. $Z$. gibbosa is an annual herb belonging to the family fabaceae. It has around 70 species in the Zornia genus, commonly known as Nellujollusoppu, and it grows at high altitudes i.e. 450-2000 $\mathrm{m}$ around India. It has been used in folklore medicine for the treatment of different ailments. ${ }^{23-25}$

\section{MATERIALS AND METHODS}

\section{Reagents and chemicals}

All reagents used for the present study were of analytical grade. Diagnostic kits were purchased from Span Diagnostics Ltd, Gujarat, India. Alloxan monohydrate was from Sigma chemicals, St Louis, USA, and Glibenclamide from Avantis Pharma Ltd.

\section{Plant material and preparation of extracts}

The plant material, Z. gibbosa, was collected at Guntur, Andhra Pradesh, India. The authentication of the plant was performed by Rtd. Prof. M. Venkaih, Department of Botany, Andhra University, Visakhapatnam (AU/DP\&P/BGR/72). The plant material aerial parts were separated and shade dried at room temperature and powdered. The powdered material was used for extraction separately with ethyl acetate and hydroalcoholic (Hyd. ext) using the maceration process. The extracted solvents were concentrated to dryness under vacuum using a rotavapour.

\section{Selection of animals}

Healthy male and female albino rats of weighing between 180$250 \mathrm{~g}$ aged 60-90 days were used for the study. The rats were housed under standard light and humidity and were supplied proper food and water ad libitum.

\section{Acute toxicity studies}

The acute toxicity study was conducted for ethyl acetate and ethanol ( $70 \% \mathrm{v} / \mathrm{v}$ ) extracts of $Z$. gibbosa as per Organisation for Economic Co-operation and Development (OECD) guidelines 420 (OECD.2001) and regulations of the Institutional Animal Ethics Committee (Reg no. 516/01/A/CPCSEA). The male albino rats were divided into two groups of 6 animals. They were maintained for one week before the experiment under room temperature and allowed free access to water and diet. The animals were subjected to an acute toxicity study using each extract at a dose of $2000 \mathrm{mg} / \mathrm{kg}$ orally in 2 groups at regular time intervals, i.e., 1, 2, 4, 8, 12 and 24 h. During this time, the animals were under observation to note different conditions such as skin changes, morbidity, aggressiveness, oral secretions, sensitivity to sound and pain, respiratory movements, and mortality. 


\section{Grouping of animals for glucose lowering test}

The experimental design consisted of 48 rats divided into eight groups. Group 1 received $0.1 \mathrm{~mL}$ of normal saline; the blood glucose of the rats was elevated by the administration of 100 $\mathrm{mg} / \mathrm{kg}$ body weight of alloxan monohydrate intraperitoneally after an overnight fast but with access to drinking water, except groups 1 . The animals were then housed in a controlled facility and allowed to drink $5 \%$ glucose solution to overcome the hypoglycemia. The hyperglycemic state was confirmed by the measurement of fasting blood glucose concentration using a glucometer with blood collected by tail vein puncture. Rats with blood glucose $\geq 200 \mathrm{mg} / \mathrm{dL}$ after $72 \mathrm{~h}$ were considered diabetic and used for the research. ${ }^{26,27}$ Group 2: normal rats treated with the ethanol $(70 \% \mathrm{v} / \mathrm{v})$ extract $500 \mathrm{mg} / \mathrm{kg}$ body weight to determine the effect of the extract on normal blood glucose levels. Group 3: diabetic untreated (animals were treated with $100 \mathrm{mg} / \mathrm{kg}$ body weight of alloxan monohydrate); group 4: diabetic animals treated with standard drug $(5 \mathrm{mg} / \mathrm{kg}$ body weight of glibenclamide); group 5: diabetic animals treated with $250 \mathrm{mg} / \mathrm{kg}$ body weight of ethyl acetate extract orally; group 6: diabetic animals treated with $500 \mathrm{mg} / \mathrm{kg}$ body weight of ethyl acetate extract orally; group 7: diabetic animals treated with $250 \mathrm{mg} / \mathrm{kg}$ body weight of ethanol (70\% v/v) extract orally, and group 8: diabetic animals orally treated with $500 \mathrm{mg} / \mathrm{kg}$ body weight of ethanol ( $70 \% \mathrm{v} / \mathrm{v})$ extract of $Z$. gibbosa.

\section{Treatment with extract and standard drug}

Extracts of $Z$. gibbosa and glibenclamide (standard drug) were dissolved in $10 \mathrm{~mL}$ normal saline $(0.9 \% \mathrm{NaCl})$ before oral administration. Respective doses of extract and standard drug were then administered to the rats once daily in the morning (09:00-10:00 AM) for twelve days and the blood glucose was checked every four days. On the seventeenth day, the rats were fasted for $12 \mathrm{~h}$ and euthanized. Blood samples were collected by carotid puncture into heparinized tubes, centrifuged at 1000 $\mathrm{r} / \mathrm{min}$ for $5 \mathrm{~min}$, and the clear serum supernatant was used immediately for the assessment of the lipid profile, and liver and kidney function tests.

\section{Serum biochemical parameters}

The biochemical parameters that were investigated includes: alanine aminotransferase (ALT), aspartate aminotransferase (AST), alkaline phosphatase (ALP), total bilirubin, total protein, and creatinine using Span diagnostics Ltd. kits, and serum electrolytes $\left(\mathrm{K}^{+}, \mathrm{Cl}^{-}, \mathrm{Na}^{+}\right)$were determined using Randox diagnostic kits.

\section{Plasma lipid profiles}

The plasma total cholesterol, triglyceride (TG), high-density lipoprotein (HDL), and low-density lipoprotein (LDL) were determined using Randox diagnostic kits. The absorbance was determined and calculated using a fully-smart semi-automated analyzer, BS Biosciences.

\section{Statistical analysis}

Results are expressed in mean \pm standard error of mean using ordinary two-way analysis of variance using GraphPad Prism-6 software. The results of $p<0.01$ were considered as significant.

\section{RESULTS}

Acute toxicity of the selected plant extracts was tested as per OECD guidelines. There were no behavior signs such as alertness, motor activity, breathlessness, restlessness, diarrhea, tremor, convulsion, and coma observed at the administered doses. The rats were physically active and no deaths were recorded in present study of extracts treated at $2000 \mathrm{mg} / \mathrm{kg}$ body weight. Therefore, the LD50 is greater than $2000 \mathrm{mg} / \mathrm{kg}$ body weight.

The glucose levels were decreased in all tested groups compared with the untreated diabetes group, which continued to have elevated levels until the animals were sacrificed. Among all doses of tested extracts, hyd. ext at $500 \mathrm{mg} / \mathrm{kg}$ body weight showed better activity in the reduction of elevated glucose levels (Figure 1) and retained the body weight of the rats (Figure 2) as the treatment moved forward, except in the diabetic untreated group. No hyperglycemia or hypoglycemia was observed in the rats treated only with the extracts.

ALT, AST, ALP, total bilirubin, total protein, creatinine levels were significantly elevated in the diabetic animals. The various doses of extracts and standard drug significantly $(p<0.01)$ restored the ameliorated levels of ALT, AST, ALP, total bilirubin, total protein, creatinine levels. Normal levels of ALT and ALP levels showed a normoglycemic condition. The hydroalcoholic extract at $500 \mathrm{mg} / \mathrm{kg}$ body weight showed better activity in the increase of reduced ALT and creatinine levels as well as the reduction of increased AST, ALP, albumin and total protein levels (Figure 3, 4).

The electrolyte levels (sodium, chloride, and potassium) were varied in the diabetes-induced groups, extracts of Z. gibbosa significantly adjusted the electrolyte levels at the tested doses, as much as standard drug (Figure 5).

LDL, TG, and cholesterol levels were increased, whereas HDL levels were decreased in the diabetic animals. The extracts of $Z$. gibbosa and standard drug significantly decreased levels of LDL, TG, and cholesterol, and increased the HDL levels ( $p<0.01$ ) (Figure 6).

\section{DISCUSSION}

DM is caused by failure to maintain a stable level of blood glucose in the face of normal fluctuations of supply and demand. The secretary product of pancreatic $\beta$-cells, insulin, is central in the pathophysiology of DM. ${ }^{28}$ Type $1 \mathrm{DM}$, or insulindependent DM, results from an absolute deficiency of insulin due to autoimmunologic destruction of the insulin-producing pancreatic $\beta$-cells. ${ }^{29}$ In type $2 \mathrm{DM}$, or non-insulin-dependent $\mathrm{DM}$, muscle and fat cells are 'resistant' to the actions of insulin and compensatory mechanisms that are activated in the $\beta$-cells to secrete more insulin are not sufficient to maintain blood glucose levels within a normal physiologic range. ${ }^{30,31}$

DM is characterized by chronic hyperglycaemia and it leads to the development of different physiologic changes in the body, and finally causes diseases. ${ }^{32-35}$ In the present study, alloxan induction was used to cause DM in the animals. It leads to 


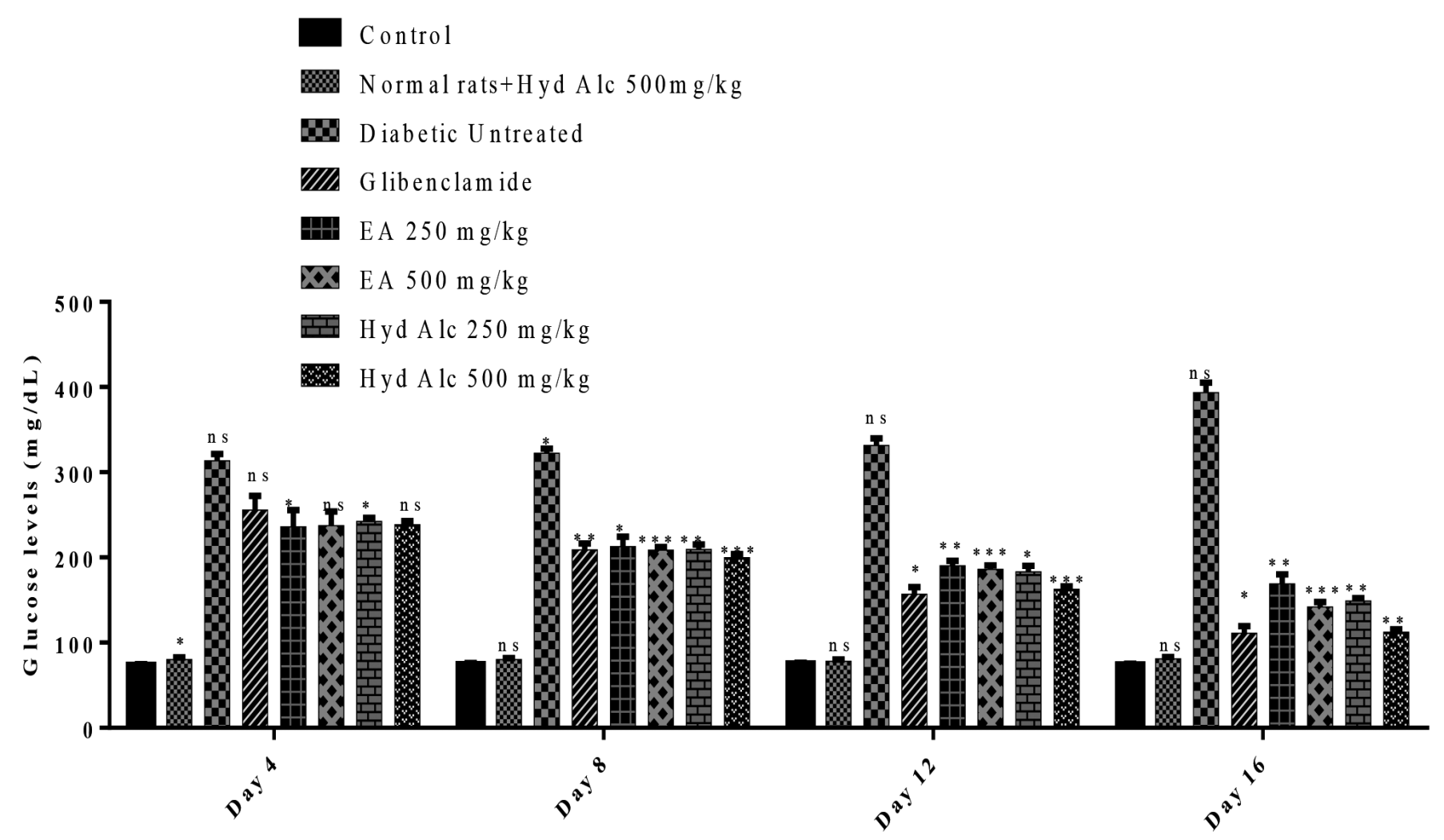

Figure 1. Glucose levels of rats in different groups

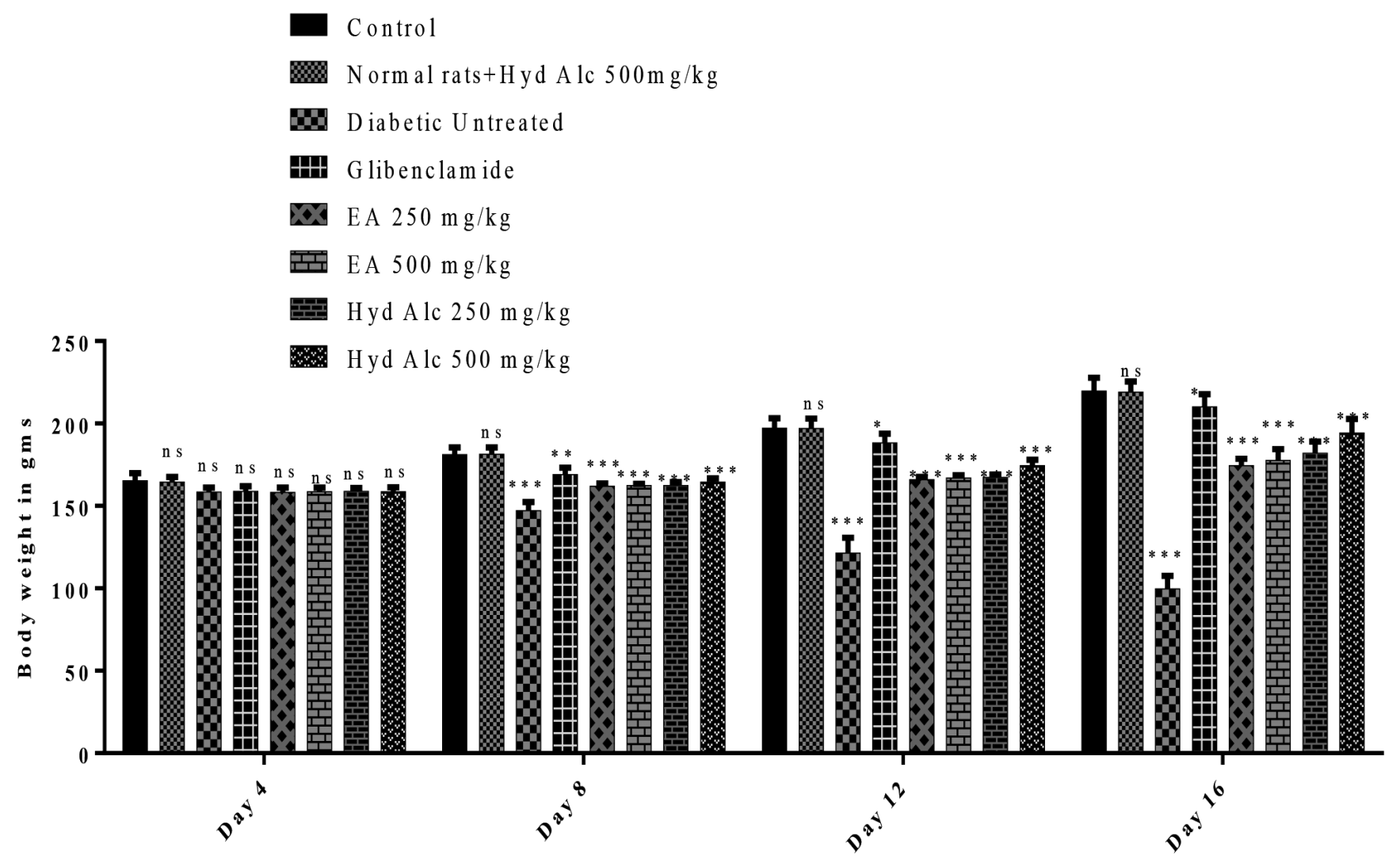

Figure 2. Body weight of the rats in different groups 


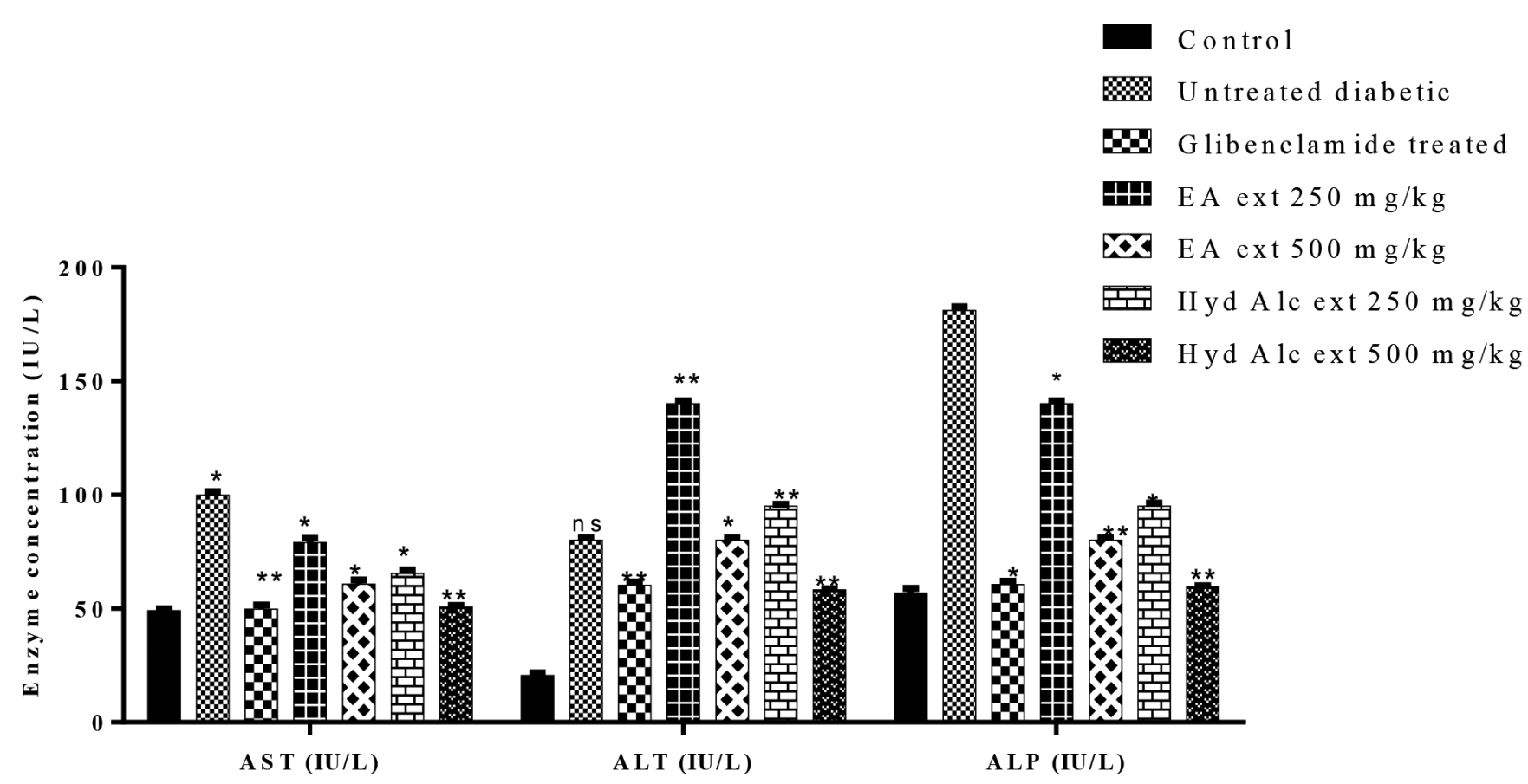

Figure 3. Effect of $Z$. gibbosa extracts on AST, ALT, ALP levels in alloxan-induced diabetic rats AST: Aspartate aminotransferase, ALT: Alanine aminotransferase, ALP: Alkaline phosphatase

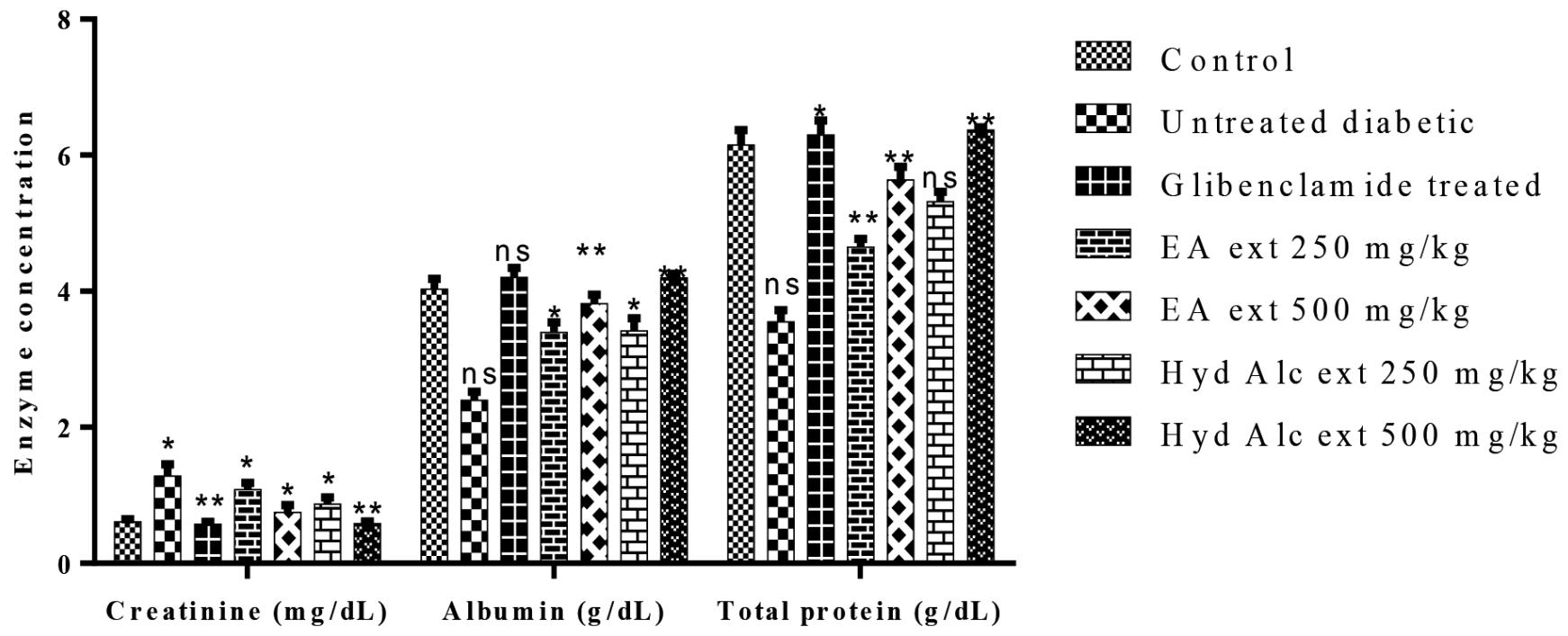

Figure 4. Effect of $Z$. gibbosa extracts on creatinine, albumin and total protein levels in alloxan-induced diabetic rats

variations in their body physiologic condition ${ }^{36,37}$ by causing necrosis to the pancreatic $\beta$-cells, ${ }^{38-40}$ this leads to a reduction in insulin production and finally altering enzymatic levels in different organ's functions in the body such as the kidneys and liver (Figure 3 to Figure 6). The tested extracts of $Z$. gibbosa showed a significant reduction of the increased blood glucose levels (Figure 1). The reduction of glucose levels by $Z$. gibbosa may have been through protection of the $\beta$-cells from undergoing necrosis., ${ }^{1,2}$ The weight loss also observed after diabetic induction was probably due to excessive breakdown of tissue proteins and lipid for energy to maintain the body organs' function, but after treatment with the extracts of $Z$. gibbosa, the animals started to regain their body weight (Figure 2). The gained body weight may be due to improved metabolic activities with normal levels of glucose in the body.

Insulin helps glucose uptake in muscle and fat and inhibits hepatic glucose production. Insulin also stimulates cell growth, differentiation, and promotes the storage of substrates in fat and muscle by stimulating lipogenesis, glycogen, and protein synthesis, and inhibiting lipolysis, glycogenolysis, and protein 
breakdown. Insulin deficiency (type 1 DM) or resistance (type $2 \mathrm{DM}$ ) results in profound deregulation of these processes, and produces elevations in fasting and postprandial glucose and lipid levels..$^{41-43}$ In the present study, elevations in electrolytes, albumin, and creatinine levels were also observed in the alloxaninduced diabetic rats and $Z$. gibbosa extracts significantly reinstated altered electrolytes, albumin, and creatinine levels in the diabetic rats (Figure 4,5 ). This means that $Z$. gibbosa extracts have the ability to protect nephron function and increase electrolyte absorption in renal tubules. ${ }^{44}$

The enzyme levels of AST, ALT, ALP, and bilirubin indicate the functioning of the liver in the body ${ }^{45,46}$ and alterations in these enzymes were observed in the alloxan-induced diabetic rats, which indicates that DM affects the functions of organs. ${ }^{47} \mathrm{Z}$. gibbosa extracts significantly revised the reduced or increased enzymes levels of the liver and its function (Figure 3) due to DM, possibly through regeneration of damaged functions due to DM.

DM causes diabetic dyslipidemia, i.e. low-density cholesterol levels (LDL) and increases TG and high-density cholesterol levels (HDL), which increases the risk for heart disease and stroke. ${ }^{48,49}$ Variations in these levels (lipid profile) were observed in the present experiment and the variations were restored in the $Z$. gibbosa extract-treated groups compared with the diabetic untreated group (Figure 6). This might be due to reduced hepatosynthesis of triglycerols or reduced

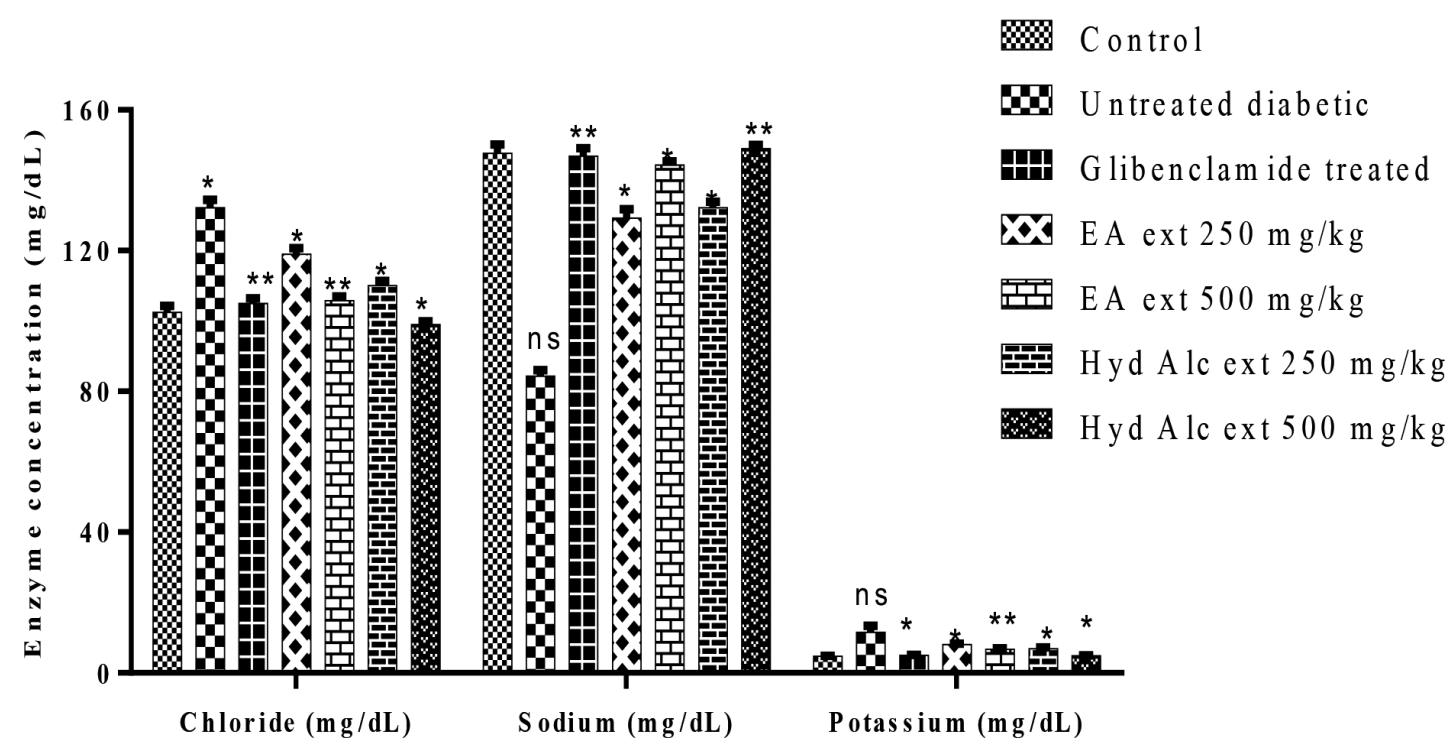

Figure 5. Effect of $Z$. gibbosa extracts on chloride, sodium and potassium levels in alloxan-induce diabetic rats

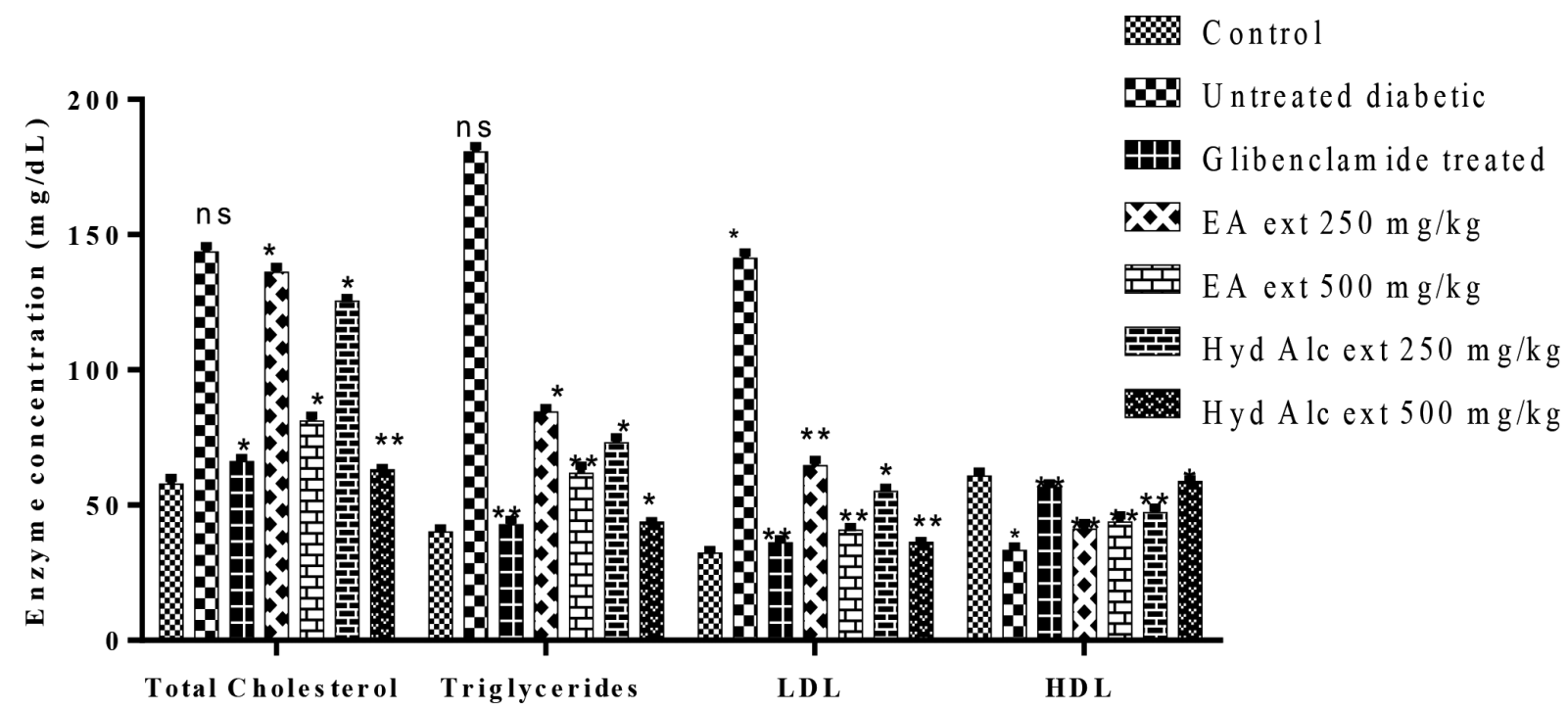

Figure 6. Effect of $Z$. gibbosa extracts in total cholesterol, triglycerides, LDL and HDL levels in alloxan-induced diabetic rats 
lipolysis because deficiency of insulin enhanced the hydrolysis of triacylglycerols. ${ }^{50,51}$ The increased HDL levels in Z. gibbosa extract-treated groups indicates that these have the ability to suppress the enzymes' action responsible for LDL formation (3-hydroxy-3-methylglutaryl coenzyme $A$ reductase) in the diabetic condition. ${ }^{52}$ From the above results, it can be summarized that, the tested extracts of $Z$. gibbosa have the ability to restore physiologic changes that occur due to the diabetes-like reduction in glucose concentrations, gaining of body weight, and failure of organs such as the kidneys and liver.

\section{CONCLUSIONS}

$\mathrm{DM}$ is a well-known chronic disorder around the world with various late complications such as retinopathy, neuropathy, and nephropathy. $Z$. gibbosa has significant antidiabetic activity (glucose lowering). Therefore, it can be used as an adjuvant medicine along with allopathic medicine in the treatment of diabetes as well as for its late complications. A further study is underway in our laboratory to isolate the active principle and to study the mechanism of its action.

\section{ACKNOWLEDGEMENTS}

The authors acknowledge the authorities of $A U$ College of Pharmaceutical Sciences for providing the necessary facilities.

Conflict of Interest: No conflict of interest was declared by the authors.

\section{REFERENCES}

1. Bell Gl, Polonsky KS. Polonsky, Diabetes mellitus and genetically programmed defects in beta-cell function. Nature. 2001;414:788-791.

2. Mathis $D$, Vence $L$, Benoist $C$. beta-Cell death during progression to diabetes. Nature. 2001; 414:792-798.

3. World Health Organization. Definition, diagnosis and classification of diabetes mellitus and its complications. Part 1: Diagnosis and classification of diabetes mellitus. Geneva; 1999.

4. Diabetes Fact sheet $N^{\circ} 312$. WHO. October 2013. Archived from the original on 26 Aug 2013. Retrieved 25 March 2014.

5. National Institute for Health and Clinical Excellence. Clinical guideline 66: Type 2 diabetes. London, 2008.

6. The American Diabetes Association Complete Guide to Diabetes, 3rd ed. Alexandria, VA: American Diabetes Association, 2002.

7. World Health Organization. Global status report on noncommunicable diseases 2010. Geneva, 2011.

8. International Diabetes Federation. p. 13. Retrieved 21 Mar 2016.

9. The top 10 causes of death Fact sheet N 310 ". World Health Organization; 2013.

10. Mathers CD, Loncar D. Projections of global mortality and burden of disease from 2002 to 2030. PLoS Med. 2006;3:442.

11. Morrish NJ, Wang SL, Stevens LK, Fuller JH, Keen H. Mortality and causes of death in the WHO Multinational Study of Vascular Disease in Diabetes. Diabetologi. 2001;44(Suppl 2):14-21.
12. Roglic G, Unwin N, Bennett PH, Mathers C, Tuomilehto J, Nag S, Connolly $\mathrm{V}$, King $\mathrm{H}$. The burden of mortality attributable to diabetes: realistic estimates for the year 2000. Diabetes Care. 2005;28:2130-2135.

13. Howlett HC, Bailey CJ. A risk-benefit assessment of metformin in type 2 diabetes mellitus. Drug Saf. 1999;20:489-503.

14. Krentz AJ, Bailey CJ. Oral antidiabetic agents: current role in type 2 diabetes mellitus. Drugs. 2005;65:385-411.

15. Stein SA, Lamos EM, Davis SN. A review of the efficacy and safety of oral antidiabetic drugs. Expert Opin Drug Saf. 2013;12:153-175.

16. Chang CL, Lin Y, Bartolome AP, Chen YC, Chiu SC, Yang WC. Herbal Therapies for Type 2 Diabetes Mellitus: Chemistry, Biology, and Potential Application of Selected Plants and Compounds. Evid Based Complement Alternat Med. 2013;2013:378657.

17. Jia W, Gao W, Tang L. Antidiabetic herbal drugs officially approved in China. Phytotherapy Res. 2003;17:1127-1134.

18. Hays NP, Galassetti PR, Coker RH. Prevention and treatment of type 2 diabetes: current role of lifestyle, natural product, and pharmacological interventions. Pharmacol Ther. 2008;118:181-91.

19. Jung M, Park M, Lee HC, Kang YH, Kang ES, Kim SK. Antidiabetic agents from medicinal plants. Curr Med Chem. 2006;13:1203-1218.

20. Gershell L. Type 2 diabetes market. Nat Rev Drug Discov. 2005;4:367368.

21. Salimifar M, Fatehi-Hassanabad Z, Fatehi M. A review on natural products for controlling type 2 diabetes with an emphasis on their mechanisms of actions. Curr Diabetes Rev. 2013;9:402-411.

22. Carpino PA, Goodwin B. Diabetes area participation analysis: a review of companies and targets described in the 2008-2010 patent literature. Expert Opin Ther Pat. 2010;20:1627-1651.

23. Pullaiah T, Ramakrishnaiah V, Sandhya Rani S, Rao PN. Flora of Guntur District Andhra Pradeh, India. Regency Publications; New Delhi; 2001:140.

24. Sawant BV, Bairy TS. Phyto-Pharmacognostical study of Zornia gibbosa Span (Samyojaki). Research \& Reviews: A Journal of Pharmacology. 2013;3:24-32.

25. Sawant BV, Bairy TS, Shrikanth P Acharya. Analgesic Activity and Acute Toxicity Study of Zornia gibbosa Span (Samyojaki) in Mice. Research \& Reviews: A Journal of Pharmacology. 2014;4:1-4.

26. Pari L, Amarnath Satheesh M. Antidiabetic activity of Boerhavia diffusa L. effect on hepatic key enzymes in experimental diabetes. $J$ Ethnopharmacol. 2004;91:109-113.

27. Yadav JP, Saini S, Kalia AN, Dangi AS. Hypoglycemic and hypolipidemic activity of ethanolic extract of Salvadora oleoides in normal and alloxaninduced diabetic rats. Indian J Pharmacol. 2008;40:23-27.

28. Expert Committee on the Diagnosis and Classification of Diabetes Mellitus. Report of the expert committee on the diagnosis and classification of diabetes mellitus. Diabetes Care. 2001;26(Suppl 1):5-20.

29. Atkinson MA, Eisenbarth GS. Type 1 diabetes: new perspective on disease pathogenesis and treatment. Lancet. 2001;358:221-229.

30. Cavaghan MK, Ehrmann DA, Polonsky KS. Interactions between insulin resistance and insulin secretion in the development of glucose intolerance. J Clin Invest. 2000;106:329-333.

31. Kahn SE. Clinical review 135: The importance of b-cell failure in the development and progression of type 2 diabetes. J Clin Endocrinol Metab. 2001;86:4047-4058. 
32. Diabetes Control and Complications Trial Research Group, Nathan DM, Genuth S, Lachin J, Cleary P, Crofford O, Davis M, Rand L, Siebert C. The effect of intensive treatment of diabetes on the development and progression of long-term complications in insulin-dependent diabetes mellitus. N Engl J Med. 1993;329:977-986.

33. Wei M, Gaskill SP, Haffner SM, Stern MP. Effects of diabetes and level of glycemia on all-cause and cardiovascular mortality. The San Antonio Heart Study. Diabetes Care. 1998;7:1167-1172.

34. Ebara T, Conde Karin, Kako Y, Liu Y, Xu Y, Ramaksishnan R, Goldberg IJ, Shachter NS. Delayed catabolism of apoB-48 lipoproteins due to decreased heparan sulfate proteoglycan production in diabetic mice. $\mathrm{J}$ Clin Invest. 2000;105:1807-1818.

35. Ginsberg HN. Insulin resistance and cardiovascular disease. J Clin Invest. 2000;106:453-458.

36. Williams SB, Goldfine AB, Timimi FK, Ting HH, Roddy MA, Simonson DC, Creager MA. Acute hyperglycemia attenuates endothelium-dependent vasodilation in humans in vivo. Circulation. 1998;97:1695-1701.

37. Du XL, Edelstein D, Rossetti L, Fantus IG, Goldberg H, Ziyadeh F, Wu J, Brownlee M. Hyperglycemia-induced mitochondrial superoxide overproduction activates the hexosamine pathway and induces plasminogen activator inhibitor-1 expression by increasing Sp1 glycosylation. Proc Nat Acad Sci USA. 2000;97:12222-12226.

38. Kliber A, Szkudelski T, Chichlowska J. Alloxan stimulation and subsequent inhibition of insulin release from in situ perfused rat pancreas. J Physiol Pharmacol. 1996;47:321-328.

39. Goldner MG, Gomori G. Studies on the mechanism of alloxan diabetes. Endocrinology. 1944;35:241-248.

40. Tasaka Y, Inoue Y, Matsumoto H, Hirata Y. Changes in plasma glucagon, pancreatic polypeptide and insulin during development of alloxan diabetes mellitus in dog. Endocrinol Jpn. 1988;35:399-404.

41. Klip A, Paquet MR. Glucose transport and glucose transporters in muscle and their metabolic regulation. Diabetes Care. 1990;13:228-243.

42. Brüning JC, Michael MD, Winnay JN, Hayashi T, Hörsch D, Accili D, Goodyear LJ, Kahn CR. A muscle-specific insulin receptor knockout exhibits features of the metabolic syndrome of NIDDM without altering glucose tolerance. Mol Cell. 1998;2:559-569.

43. Abel ED, Peroni O, Kim JK, Kim YB, Boss O, Hadro E, Minnemann T, Shulman Gl, Kahn BB. Adipose-selective targeting of the GLUT4 gene impairs insulin action in muscle and liver. Nature. 2001;409:729-733.

44. Day A, Mayne P, Mayne PD. Clinical chemistry in diagnosis and treatment. 6th ed. London; CRC Press; 1994.

45. LaRosa JC, Grundy SM, Waters DD, Shear C, Barter P, Fruchart JC, Gotto AM, Greten H, Kastelein JJ, Shepherd J, Wenger NK; Treating to New Targets (TNT) Investigators. Intensive lipid lowering with atorvastatin in patients with stable coronary disease. N Engl J Med. 2005;352:14251435.

46. Snow V, Aronson MD, Hornbake ER, Mottur-Pilson C, Weiss KB; Clinical Efficacy Assessment Subcommittee of the AmericanCollege of Physicians. Lipid control in the management of type 2 diabetes mellitus: a clinical practice guideline from the American College of Physicians. Ann Intern Med. 2004;140:644-650.

47. Green RM, Flamm S. AGA technical review on the evaluation of liver chemistry tests. Gastroenterology. 2002;123:1367-1384.

48. Pfeffer MA, Keech A, Sacks FM Cobbe SM, Tonkin A, Byington RP, Davis BR, Friedman CP, Braunwald E, et al. Safety and tolerability of pravastatin in long-term clinical trials: prospective Pravastatin Pooling (PPP) Project. Circulation. 2002;105:2341-2346.

49. Heart Protection Study Collaborative Group. MCR/BHF Heart Protection Study of cholesterol lowering with simvastatin in 20,536 high-risk individuals: a randomised placebo-controlled trial. Lancet. 2002;360:7-22.

50. Gagne C, Bays HE, Weiss SR, Mata P, Quinto K, Melino M, Cho M, Musliner TA, Gumbiner B; Ezetimibe Study Group, et al. Efficacy and safety of ezetimibe added to ongoing statin therapy for treatment of patients with primary hypercholesterolemia. Am J Cardiol. 2002;90:1084-1091.

51. Crouse JR. Hypertriglyceridemia: a contraindication to the use of bile acid binding resins. Am J Med. 1987;83:243-248.

52. Saltiel AR, Kahn CR. Insulin signalling and the regulation of glucose and lipid metabolism. Nature. 2001;414:799-806. 